\title{
Erratum to: Holistic Leadership
}

\author{
Satinder Dhiman
}

(C) The Author(s) 2017

S. Dhiman, Holistic Leadership,

DOI 10.1057/978-1-137-55571-7

DOI 10.1057/978-1-137-55571-7_12

The original version of the book was published without the source for Fig.1.1, 1.2 and 9.1

The source name is given below for these figures:

Figure 1.1. Cycle of holistic leadership, Satinder Dhiman (2016)

Source: Conceptual cycle of leadership, Manoj Chandra Handa (2015); personal communication, September 18, 2015.

Figure 1.2. Holistic leadership framework, Satinder Dhiman (2016)

Source: Conceptual framework of leadership, Manoj Chandra Handa (2015); personal communication, September 7, 2015.

The updated original online version for this chapter can be found at DOI 10.1057/978-1-137-55571-7_1 
Figure 9.1. Adapted from Seven Habits of Highly Fulfilled People framework, Satinder Dhiman (2012/2014)

Visual design adapted from Conceptual framework of leadership, Manoj Chandra Handa (2015).

The updated original online version for this chapter can be found at DOI 10.1057/978-1-137-55571-7_9 